\title{
各種血液浄化療法における血圧低下頻度
}

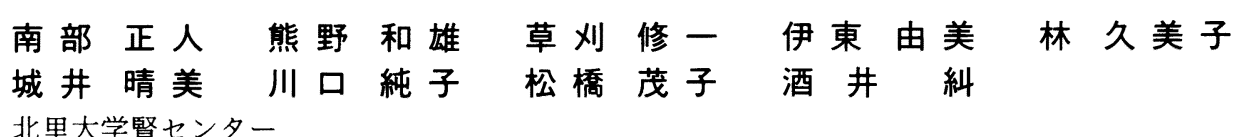

(昭和 59 年 9 月 3 日受付)

key words：透析性血圧低下，低温度透析，血液濾過透析，血液濾過，深部体温

〈要旨〉

維持透析患者の血圧状態を調查するとともに, 低血圧症例に各種の血液浄化治療に加えて低温透析を行い若干の知 見を得たので報告する。

維持透析患者 374 名の血圧調査の集計結果は, 高血圧群 $14.7 \%$, 正常血圧群 $78.3 \%$, 低血圧群 $7.0 \%$ の頻度であっ た. これら 3 群での透析中の血圧低下頻度は，いずれの血圧群にあっても $31 \%$ の出現率であった。透析中に血圧低下 を来たす 9 症例の治療に際し常温透析から低温透析に変更したところ, 収縮期血圧は 106.2 119.0 から $127.8 \pm 19.6$ $\mathrm{mmHg}$ と有意に $(p<0.01, n=9)$ に上昇し, 拡張期血圧, 心拍数に差は認めなかった。また, 深部体温測定につい ては, 常温透析において胸部深部温と足底深部温の間に収束を認め, 低温透析では収束を認めず, このことは末梢血 管抵抗増加を示唆した。

各種血液浄化治療中の血圧低下頻度は，常温透析 $30.9 \%$, 低温透析 $18.9 \%, \mathrm{Na} 145$ 透析 $17.6 \%, \mathrm{HDF} 16.7 \%$, お よび HF 15.7\% であった。これらの成績から低温透析は低血圧症例での透析法として有用な方法と考える.

\section{Various Modes of Hemopurification for Dialysis-induced Hypotension}

Masahito Nambu, Kazuo Kumano, M. D., Shuichi Kusakari, Yumi Ito, Kumiko Hayasi, Harumi Kii, Sumiko Kawaguti, Shigeko Matsuhasi, and Tadasu Sakai, M. D.

Kidney Center, Kitasato University Hospital

Dialysis-induced hypotension interferes with adequate removal of fluid and sufficient correction of uremia, which might sometimes initiate a vicious cycle in the clinical status. This study was planned to determine the effectiveness for dialysis-induced hypotension of various modes of hemopurification. According to the analysis of the predialysis blood pressure in 374 patients on maintenance hemodialysis, $14.7 \%$ were hypertensive, $78.3 \%$ were normotensivè and $7.0 \%$ were hypotensive. Dialysis-induced hypotension occurred equally at $31 \%$ in each of the three groups. The occurrence of hypotension during various modes of treatment was $30.9 \%$ in the case of conventional dialysis (C. HD), 18.9\% in cold dialysate dialysis (cold HD), 17.6\% in high-sodium dialysate (145 $\mathrm{mEq} / l$ ) dialysis (HS. HD), $16.7 \%$ in hemodiafiltration (HDF) and $15.7 \%$ in hemofiltration (HF). The cold HD significantly increased the systolic blood pressure to $127.8 \pm 19.6 \mathrm{mmHg}$ (mean \pm 1 SD), from $106.2 \pm 19.9$ $\mathrm{mmHg}$ at the time of $\mathrm{C}$. $\mathrm{HD}$, although it did not increase the diastolic pressure nor the heart rate. From the study of the core temperature, this increase in systolic blood pressure seemed to be due to increased resistance of the peripheral vessels. These results indicate that cold HD was not only effective for dialysis-induced hypotension as well as HS. HD, HF and HDF but also has the advantage of not requiring any special equipment.

\section{緒言}

血液浄化療法の進歩発展とともに透析患者の生存率も

南部 正人 北里大学病院腎センター

厂 228 相模原市北里 1-15- 1 （0427-78-8651）
向上し慢性低血圧を示す症例，さらに透析中に血圧低下 を来たす透析困難症も多くみられる.そこで維持透析患 者の血圧調査を行うとともに, 低血圧症例に各種の血液 浄化治療, 特に低温透析を行い若干の知見を得たので報 告する。 


\section{対象・方法}

北里大学病院および関連病院で管理されている維持透 析患者 374 名（男 231 名，女子 142 名，年齢 19～82 歳， 平均年齢 36 歳，透析期間 $1 \sim 163$ 力月. 平均透析期間 62.3 力月）を対象として血圧調查を行った.

高血圧群 (収縮期血圧 $161 \mathrm{mmHg}$ 以上), 低血圧群 (収 縮期血圧 $100 \mathrm{mmHg}$ 以下), 正常血圧群の 3 群に分類し た。さらに，これら 3 群における透析中の血圧低下（透 析前収縮期血圧の $30 \%$ 低下，補液 $200 \mathrm{~m} l$ 以上）頻度を 求めた。また，低血圧症例に対し常温透析，低温透析， 透析液 $\mathrm{Na} 145 \mathrm{mEq} / \mathrm{l}$ 透析 (以下 $\mathrm{Na} 145$ ), 血液濾過透 析 (以下 $\mathrm{HDF}$ ), 血液濾過（以下 $\mathrm{HF}$ ) 治療における治 療中の血圧低下頻度について検討した。

透析中に血圧低下を来たす 9 症例に，血圧低下時に常 温透析より低温透析に変更し，血圧，心拍数抢よび一部 症例にて深部体温（胸部深部温，足底深部温）を測定し 比較検討した。

血液浄化器は AM 10, B1-L を使用し, 血液流量は 150 〜200 $\mathrm{ml} / \mathrm{min}$ とした。体重減少は dry weight を目標と して透析時間内 ( 5 時間) に行った。透析液は $\mathrm{AK}$ solita $\mathrm{C}$ (組成: $\mathrm{Na} 138, \mathrm{~K} 2.6, \mathrm{Cl} 111, \mathrm{Ca} 2.8, \mathrm{Mg} 1.5, \mathrm{HCO}_{3}{ }^{-}$ $27, \mathrm{CH}_{3} \mathrm{COO}^{-} 10 \mathrm{mEq} / l$, 置換液は HF solita（組成： $\mathrm{Na}$

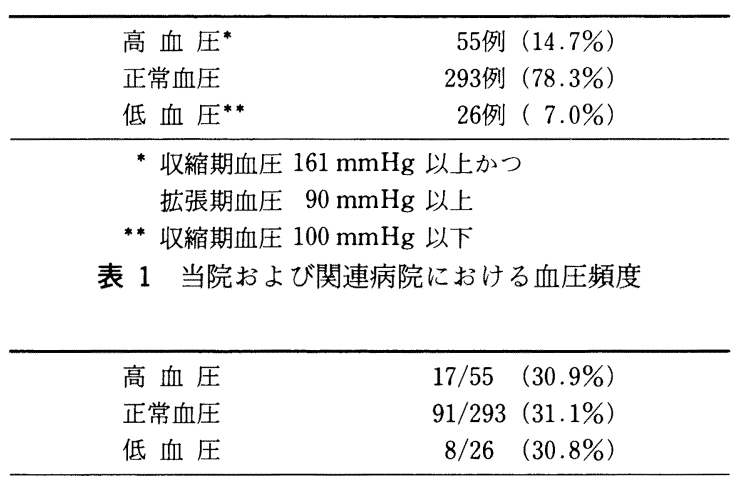

表 2 透析中の血圧低下 $30 \%$ 以上低下かつ補液 $200 \mathrm{~m} l$ 以 上頻度
138, K 2.0, Cl 108, Ca 3.8, Mg 1.5, lactate $38 \mathrm{mEq} / t$ ) 用い $\mathrm{HDF} 10 l$, HF $20 l$ の置換とした。透析温度は常温 透析で $37.5^{\circ} \mathrm{C}$, 低温透析では $34^{\circ} \mathrm{C}$ した。深部体温測定 にはコアテンプ model CTM 204, プローブは熱流補償 型 PD-1（テルモ）を用いた。

\section{結果}

1. 当院および関連病院の維持透析患者 374 名の血圧 調査結果について

血圧調查の結果については，高血圧群 $14.7 \%$, 正常血 圧群 $78.3 \%$, 低血圧群 7.0\%の頻度（表 1 ）であった。

先の 3 群における透析中の血圧低下頻度については, 高血圧群 30.9\% (17/55), 正常血圧群 31.1\% (91/293), 低血圧群 30.8\%（8/26）の頻度（表 2 ）で認められた。 これら 3 群の年齢は各々平均 46 歳で差は認めず, 透析期 間については高血圧群の順に平均 44.5 力月, 60.0 力月, 82.4 力月と有意差 $(\mathrm{p}<0.001)$ を認めた。また心胸比 (CTR) については高血圧群で平均 $50.7 \%$ で他の 2 群の 平均 $45.7 \% ， 46.6 \%$ に比し有意 $(\mathrm{p}<0.001)$ に大きかっ た。 1 回透析あたりの体重減少は 3 群ともに平均 $1.7 \mathrm{~kg}$ で，へマトクリット值 (HCT) も 3 群ともに平均 $25 \%$ で 有意差は認めなかった。

この中で, 高血圧群の透析期間が低血圧群に比し有意 $(\mathrm{p}<0.001)$ に短 $<, \mathrm{CTR}$ は有意 $(\mathrm{p}<0.001)$ に大き く,また 3 群の透析中の血圧低下頻度が同一な事流興味 深い結果（表 3 ）であった。

2. 透析中の血圧低下時に常温透析から低温透析に変 更後の血圧，心拍数の比較検討について

血圧低下時に常温 $\left(37.5 \pm 0.3^{\circ} \mathrm{C}\right)$ から低温（33.8土 $0.8^{\circ} \mathrm{C}$ ) に移行後徐々に血圧上昇を認めた（図 1 ).

透析中に血圧低下を来たす 9 症例の収縮期血圧は $106.2 \pm 19.9$ から $127.8 \pm 19.6 \mathrm{mmHg}$ と有意 $(\mathrm{p}<0.01$, $\mathrm{n}=9)$ に上昇し，拡張期血圧 $(60.0 \pm 15.4$ から $73.8 \pm$ $18.7 \mathrm{mmHg})$ ，心拍数 $(81.3 \pm 14.7$ から $79.8 \pm 13.4$ beats/min）に差は認めなかった（図 2 ).

3. 常温透析と低温透析における深部体温（中枢：胸 部深部温，末梢：足底深部温）の動態について

\begin{tabular}{|c|c|c|c|c|c|c|}
\hline & $\begin{array}{l}\text { 平均血圧 } \\
(\mathrm{mmHg})\end{array}$ & $\begin{array}{l}\text { 年齢 } \\
\text { (歳) }\end{array}$ & $\begin{array}{c}\text { 透析期間 } \\
(\text { 月) }\end{array}$ & $\begin{array}{c}-\Delta \mathrm{BW} \\
(\mathrm{kg})\end{array}$ & $\begin{array}{l}\text { CTR } \\
(\%)\end{array}$ & $\begin{array}{l}\mathrm{Hct} \\
(\%)\end{array}$ \\
\hline $\begin{array}{l}\text { 高血圧群 } \\
\qquad \mathrm{n}=55\end{array}$ & $\begin{array}{l}121.1 \\
\quad \pm 10.1\end{array}$ & $\begin{array}{l}47.6 \\
\quad \pm 14.4\end{array}$ & $\begin{array}{l}44.5 \\
\quad \pm 37.6\end{array}$ & $\stackrel{1.8}{ \pm 1.1}$ & $\begin{array}{l}50.7 \\
\quad \pm 5.2\end{array}$ & $\begin{array}{l}24.0 \\
\quad \pm 4.0\end{array}$ \\
\hline $\begin{array}{l}\text { 正常血圧群 } \\
n=239\end{array}$ & $\begin{array}{l}90.9 \\
\quad \pm 9.4\end{array}$ & $\begin{array}{l}44.1 \\
\quad \pm 13.7\end{array}$ & $\begin{array}{l}60.0^{*} \\
\quad \pm 40.7\end{array}$ & $\begin{array}{l}1.7 \\
\pm 0.9\end{array}$ & $\begin{array}{l}46.7^{*} \\
\quad \pm 5.1\end{array}$ & $\begin{array}{l}25.3 \\
\quad \pm 5.2\end{array}$ \\
\hline $\begin{array}{l}\text { 低血圧群 } \\
n=26\end{array}$ & $\begin{array}{l}67.6 \\
\pm 6.5\end{array}$ & $\begin{array}{l}47.8 \\
\quad \pm 12.0\end{array}$ & $\begin{array}{l}82.4^{*} \\
\quad \pm 46.1\end{array}$ & $\stackrel{1.8}{ \pm 0.8}$ & $\begin{array}{l}45.7^{*} \\
\pm 5.3\end{array}$ & $\begin{array}{l}25.0 \\
\pm 3.5\end{array}$ \\
\hline
\end{tabular}

表 3 当院および関連病院の維持透析患者 374 名の血圧調査 


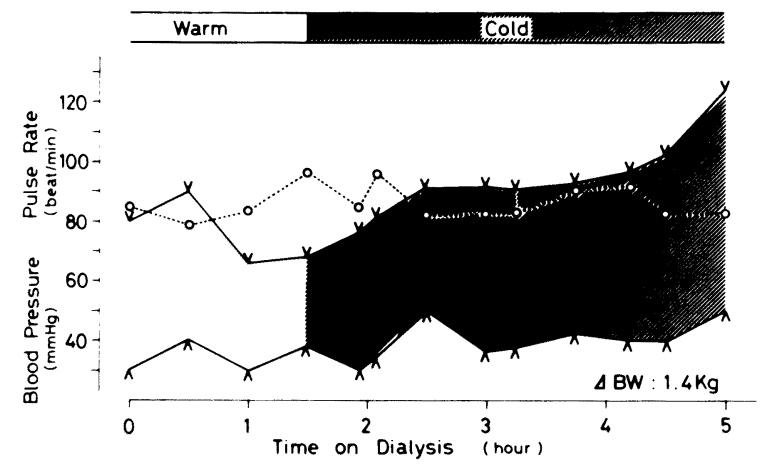

図 1 常温透析より低温透析に移行後の血圧, 脈拍数の 経時的変化（移行後徐々に血圧の上昇を認める）

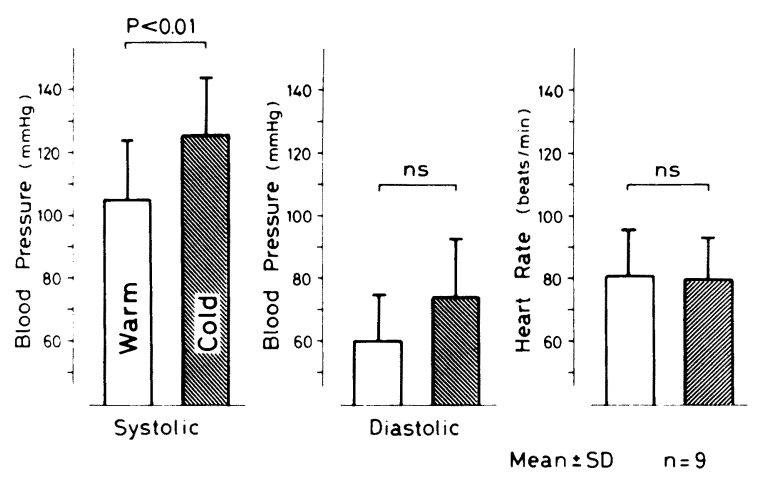

図 2 常温透析と低温透析における血圧（収縮期, 拡張 期), 心拍数の比較 (収縮期血圧にのみ有意の上昇 を認めた)

常温透析において胸部深部温は治療前後 $\left(36.8 \pm 0.1^{\circ} \mathrm{C}\right.$ VS $37.0 \pm 0.1^{\circ} \mathrm{C}, \mathrm{n}=2$ ) に変化を認めず，一方，足底 深部温は $34.6 \pm 1.1^{\circ} \mathrm{C}$ から治療 2 時間目より $36.0 \pm$ $0.4^{\circ} \mathrm{C}$ と上昇を認め, さらに治療後 $36.1 \pm 0.1^{\circ} \mathrm{C}$ と胸部温 と足底温の間に収束を認めた。低温透析においては，治 療前後の胸部温は $36.7 \pm 0.5 \mathrm{VS} 36.2 \pm 0.2^{\circ} \mathrm{C}, \mathrm{n}=4$ と 変化は認めず, また足底温は $34.8 \pm 1.3 \mathrm{VS} 34.1 \pm 1.0^{\circ} \mathrm{C}$ と変化は認めなかった。 また胸部温と足底温の温度差も 認めなかった（図 3 ).

4. 各種血液浄化治療中の血圧低下頻度について 各種血液浄化治療中の血圧低下頻度は，常温 $30.9 \%$ $(80 / 259,15$ 症例 $)$, 低温 $18.9 \%(10 / 53,7$ 症例 $), \mathrm{Na}$ $14517.6 \%$ (13/74, 5 症例), HDF 16.7\% (14/84, 7 症例), HF 15.7\% (11/70, 7 症例) の頻度であった（図 4 ). この成績から, 低温透析は低血圧症例での透析とし て有用な方法といえる.また, Na 145 との併用によって, より有効な治療法になりうると考え現在検討中である.

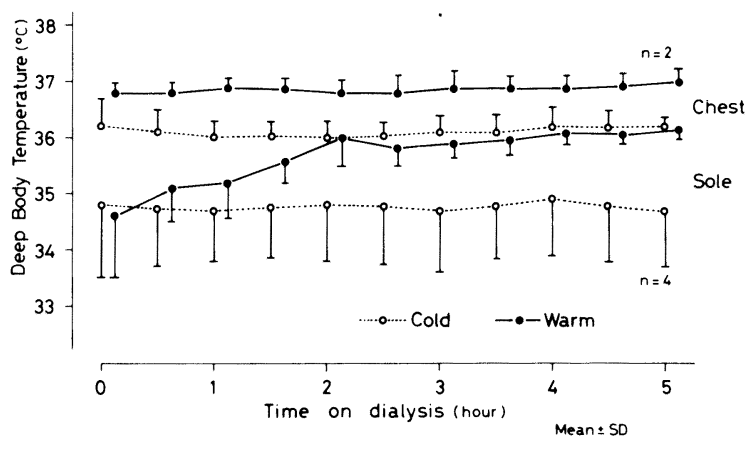

図 3 常温透析と低温透析における深部体温（中枢：胸 部, 末梢 : 足底部) の経時的変化

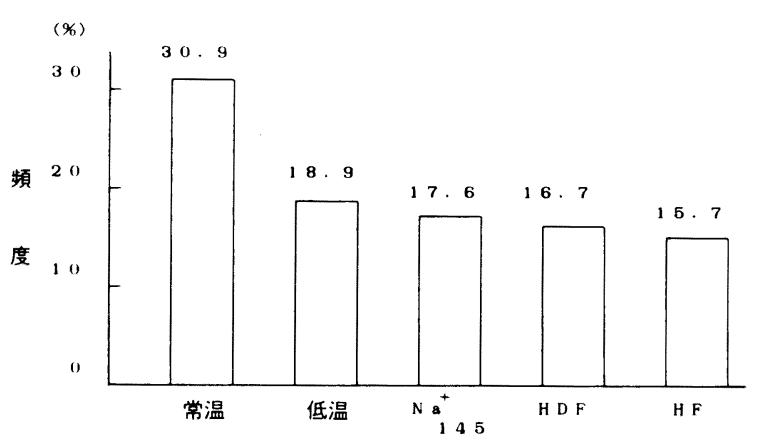

図 4 各種血液浄化治療中の血圧低下頻度

\section{考察}

北里大学病院腎センターおよび関連病院において管理 されている維持透析患者 374 名を対象として血圧調査を 行った。高血圧群の頻度は $14.7 \%$, 正常血圧群 $78.3 \%$, 低血圧群 $7.0 \%$ であった。 さらにこれら 3 群における透 析中の血圧低下頻度は, 高血圧群 $30.9 \%$, 正常血圧群 $31.1 \%$, 低血圧群 $30.8 \%$ であった. 透析患者の低血圧症 例については，木嶋ら ${ }^{1)}$ は $22.1 \%$ ，三村ら ${ }^{2)}$ は $6.7 \%$ と報 告している。このような慢性低血圧を示す症例, さらに 透析中に血圧低下を来たす透析困難症も多くみられる。 二瓶ら ${ }^{3)}$ は低血圧症における透析中の血圧低下頻度は $21.4 \%$ と報告している．

これら透析中の血圧低下に関しては多くの因子が関 与4)している.まず第 1 に hypovolemia, ついで acetate の負荷, 血圧調節機構（自律神経機能低下，血管反応性 低下), 心筋予備力低下などが主として生体側の因子とし て挙げられる。 その対策として, 第 1 に水分, 溶質除去 速度の適正化, ついで透析液 $\mathrm{Na}$ 濃度の変更（溶質の浸 透圧効果, 循環血漿量の維持), 透析液の buffer の変更 (acetate から bicarbonate へ), 透析温度の変更 (常温 から低温へ) などが挙げられる。 
さてこの低温透析についての評価であるが，我々の成 績から各種血液浄化治療中の血圧低下頻度は常温透析に 比し低温, Na 145, HDF, HF の順に低い。また血圧低 下時に常温より低温に移行後, 収縮期血圧の上昇を認め, 拡張期血圧, 心拍数には差を認めなかった.このことは, 心臟の 1 回拍出量の増加を示唆するものと思われ, 低温 刺激によるノルエピネフィリン (NA) の分泌増加も考 慮すると，この NA が心臓の $\beta$ 作用 (inotropic action) を刺激していると思われる。

また，深部体温について見ると常温透析において胸部 深部温と足底深部温の収束を認め, 低温透析では両深部 温に変化を認めなかった. 常温透析における深部体温の 収束は末梢での血管拡張による血流増加を示唆するもの と考えられ，この末梢での血管拡張が低血圧の 1 因とな るものと思われる。また低温透析では足底深部温は上昇 せず常温透析にみられる血管拡張はないものと思われ， この事が末梢血管抵抗増加を示唆するものと考える. Maggiore ら ${ }^{5,6)}$ は血圧維持に対する低温透析の有用性を 報告している。そのメカニズムとして Mahida ら゙はカ テコールアミン (NA) が分泌され ${ }^{8)}$ ，梢血管抵抗が増 加するとし透析中の血圧低下は常温 $19.3 \%$ に比し, 低温 で $3.97 \%$ と有意に少ないとしている.Coli ら ${ }^{99}$ は hemodynamic の検討より低温透析により血圧が維持さ れ，末梢血管抵抗が増加するとしている．しかしながら， 今回我々はこれらの詳細なる循環動態は検討しておら ず，今後さらに検討を要するものと思われる.

\section{結語}

1）北里大学病院腎センターおよび関連病院において 管理されている維持透析患者 374 名を対象として血圧調 查を行った。

血圧頻度は高血圧群 $14.7 \%$, 正常血圧群 $78.3 \%$, 低血 圧群 $7.0 \%$ であった。さらにこれら 3 群の透析中の血圧 低下頻度は各々の群で平均 $31 \%$ に認められた。

2 ）透析中の血圧低下時に常温から低温に移行後血圧 上昇を認めた。また収縮期血圧は有意に上昇し，拡張期 血圧, 心拍数には差を認めなかった。

3 ) 常温透析において, 胸部温と足底温の間に収束を 認め, 低温透析では認めなかった。この事により低温透 析において末梢血管抵抗増加を示唆した。

4 ）各種血液浄化治療中の血圧低下頻度は, 常温透析 $30.9 \%$, 低温透析 $18.9 \%$, NA $14517.6 \%$, HDF $16.7 \%$, HF 15.7\% の頻度であった。

5 ) 低温透析は, 透析中に血圧低下を来たす症例に対 し有効であり, また透析液 $\mathrm{Na}$ 濃度 $145 \mathrm{mEq} / l$ の併用 は他の净化法に比し簡便に行え，さらに有用な方法にな るものと考える.
稿を終るにあたり，今回の血圧調査にご協力いただきまし たあけほの病院・南郷英明先生, 相模台病院・高橋裕一郎先 生, 橋本クリニック・桜井健治先生に深謝いたします。

本論文の要旨は, 第 26 回日本腎臟学会総会, 第 29 回人工 透析研究会において報告した。

\section{文献}

1）木嶋祥麿，笹岡拓雄，金山正明，久保田智，嘉手川 裕司：長期透析患者にみられる低血圧症とその対 策について(第 1 報)。腎と透析，7（3）；303-311， 1979.

2）三村信英，二瓶 宏，西村重敬，鈴木好夫，原 茂 子, 南方 保: 長期透析患者の血圧推移. 腎と透析, 10 ( 2)；145-158, 1981.

3）二瓶 宏, 三村信英：透析と高血圧, 頻度・合併症. 腎と透析，9（1）；77-81，1980.

4）平沢由平，田尻正記，相沢義房：透析低血圧。腎と 透析, 10 (2) : 301-309, 1981.

5) Maggiore, Q., Pizzarelli, F., Zoccali, C., Sisca, C., Nicolo, F., and Parlong, S. : Effect of extracorpreal blood cooling on dialytic arterial hypotension. Proc Eur Dial Transplant Assoc, 18; 597 $-602,1981$.

6) Maggiore, Q., Pizzarelli, F., Sisca, S., Zoccali, C., Parlongo, S., Nicolo, F., and Creazzo, G. : Blood temperature and vascular stability during hemodialysis and hemofiltration, Trans Am Soc Artif Intern Organs, 28 ; 523-527, 1982.

7) Mahida, B. H., Dumler, F., Zasuwa, G., Fleg, G., and Levin, N.W.: Effect of cooled dialysate hemodialysis (CHD) on serum catecholamines and blood pressure stability. Trans Am Soc Artif Intern Organs. $29 ; 384-389,1983$.

8）南部正人, 伊東由美, 草刚修一, 今井 了, 熊野和 雄, 酒井 紏：カテコールアミン動態による滤過と 拡散の差異の解明。人工藏器, 13 ( 2) : 681-684, 1984.

9) Coli, U., Landini, S., Lucatello, S., Fracasso, A., Morachiello, P., Righetto, F., Scanferla, F., Onesti, G., and Bazzato, G. : Cold as cardiovascular stabilizing factor in hemodialysis : hemodynamic evaluation, Trans Am Soc Intern Organs, $29 ; 71$ $-75,1983$. 